\title{
Espacios nacionales y espacios regionales. Conflictos y concertaciones en las fronteras chaqueñas de Argentina, Bolivia y Paraguay
}

\author{
Beatriz J. Figallo
}

PUCA-CONICET, Argentina

\begin{abstract}
Desde fines del siglo XIX y hasta mediados del XX, el Gran Chaco constituyó, en procesos asimétricos ejercidos por los estados que terminaron dividiéndose su jurisdicción, la Argentina, Bolivia y Paraguay, una región de disputas, que incluyó guerras, militarización de límites, forzada incorporación en los desarrollos industrializadores y colonizadores. Este trabajo busca conocer la ejecución de aquellas políticas y las resistencias generadas, en espacios que fueron tanto de concertaciones, como de conflictos frente al poder y a la violencia ejercida sobre sus pobladores, indios, mestizos y blancos. El objetivo es también contribuir a enriquecer la historia de las relaciones interamericanas, a través de una perspectiva antropológica, en donde actores no estatales configuran vínculos entre pueblos y gobiernos, y asimismo de una mirada que se dirija simultáneamente hacia la consideración de los contextos nacionales y regionales, en donde fronteras y límites son nociones y realidades a analizar.
\end{abstract}

Palabras Clave: Gran Chaco, Argentina, Bolivia, Paraguay, región, fronteras, límites, soberanía, violencia, indígenas, militares.

From the end of the nineteenth century until the middle of the twentieth, the Gran Chaco was a zone of conflict. Argentina, Bolivia and Paraguay exercised varied and competing influences in the region, reflecting the intentions of each nation to incorporate the Chaco forcibly as part of larger projects of industrialisation and colonisation. This study examines the implementation of these projects, as well as the resistance they generated in the face of the violence visited upon the inhabitants of the region, whether indigenous peoples, mestizos, or whites. From an anthropological perspective, the work also reassesses conflicts in the Chaco region as a problem in the history of inter-American relations, where non-governmental actors determine links between people and government. The article goes on to consider the national and regional contexts to conflict, in which frontiers and boundaries are further concepts and realities to be assessed.

Keywords: Gran Chaco, Argentina, Bolivia, Paraguay, region, frontier, border, borderlands, sovereignty, violence, indigenous peoples, military.

\section{Introducción}

La Guerra del Chaco constituye a nuestro entender un poderoso núcleo de investigación, en cuyo estudio y ponderación confluye, en intelectual convergencia, el conocimiento y la comprensión de procesos y 
fenómenos históricos que involucraron con intensidad a todos los países del Cono Sur. Sus antecedentes, su desarrollo y sus consecuencias han generado una amplia producción de historia diplomática, política, militar, ideológica y económica, sobretodo en las naciones que se enfrentaron militarmente entre 1932 y 1935, Bolivia y el Paraguay, pero también en los países que de diversas maneras estuvieron involucrados en la lenta escalada de conflictos previos y en las negociaciones pacificadoras posteriores.

Ha sido historiográficamente relevante vincular el conflicto chaquense, por ejemplo, con una renovación de la atención de Brasil por sus vínculos con el corazón sudamericano, produciendo una redefinición de sus relaciones con la Argentina, debido a los reales o imaginarios designios mutuos de expandirse o de lograr mayor influencia sobre la región; ${ }^{1}$ con la defensa de los efectivos o potenciales intereses argentinos en Paraguay y Bolivia, con la vitalidad de la diplomacia porteña que se imaginaba a sí misma singular, y que obtenía, al menos, desde lo formal, logros concretos ${ }^{2}$ con el incremento de una posición equidistante, pero que a la vez favoreciera su perfil de centro proveedor e intermediario de productos y bienes, y de nación independiente apta para formular políticas de conciliación en el caso del Uruguay; ${ }^{3}$ con una obligada presencia y opinión peruana en las disputas territoriales que afectaran a Bolivia, ${ }^{4} \mathrm{y}$, por último, con un respaldo chileno para que el gobierno de La Paz obtuviera una salida por el este, eliminando sus aspiraciones de obtenerla por el Pacífico, mientras no dejaba de intentar desempeñar una función de fuerza de equilibrio, al menos en el plano diplomático. ${ }^{5}$

1 Bieber, León E.: “A guerra do Chaco e as relaçôes brasileiro-bolivianas no período 19301945. Um caso de reorientaçâo da política exterior do Brasil”, Ibero-Amerikanisches, n. o 3-4, Berlín, 1996; Gordim da Silveira, Helder: Argentina x Brasil: a questao do Chaco Boreal, EDIPUCRS, Porto Alegre, 1997; Monteoliva Doratioto, Francisco Fernando: "As políticas da Argentina e do Brasil em relacao a disputa boliviano-paraguaia pelo Chaco (1926-1938)", Los años 30: vinculaciones y espejismos, Río de Janeiro, 1999.

2 Porcelli, Luis A.: Argentina y la Guerra por el Chaco Boreal, Centro Editor de América Latina, Buenos Aires, 1991; Brezzo, Liliana y Figallo, Beatriz: La Argentina y el Paraguay, de la guerra a la integración. Imagen histórica y relaciones internacionales, Instituto de Historia-Facultad de Derecho y Ciencias Sociales-Pontificia Universidad Católica, Rosario, 1999, pág. 289-352; Lanús, Juan Archibaldo: Aquel apogeo. Política internacional argentina.1910-1939, Emecé, Buenos Aires, 2001, págs. 494-542.

3 Rout, Leslie B.: Politics of the Chaco Peace Conference. 1935-1939, Institute of Latin American Studies, University of Texas, Austin, 1970, pág. 60.

4 Ibídem., págs. 61-2.

5 Jeffs, Leonardo: "La Guerra del Chaco y sus implicancias para las relaciones chileno-bolivianas", ponencia, V Jornadas de Historia de las Relaciones Internacionales, Santiago de Chile, 2001. 
Si desde la historia de las relaciones interamericanas se sigue privilegiando el rol del Estado como protagonista y diseñador de las acciones exteriores de los países, crecientemente se suman enfoques que tienden a hacer progresar la especialidad, a través de una visión antropológica, en donde actores no estatales desempeñan un papel importante en la configuración de los contactos entre los pueblos y sus gobiernos, y asimismo de una mirada que se dirige simultáneamente hacia contextos nacionales y regionales, en donde fronteras y límites son realidades a considerar.

Durante los últimos años, las investigaciones y los estudios sobre el tema de las fronteras han experimentado un renovado interés, vinculado a la formación de nuevos bloques económicos y a un discurso que propone un mundo sin divisiones, ofreciendo variaciones y complejizaciones teóricas —entendido esto como una conceptualización de lo no simple- ${ }^{6}$ sobre la clave interpretativa turneriana. ${ }^{7}$ El concepto de frontera, asimilado al de límite geográfico de un país, a menudo línea artificial del confín de un estado, ha sufrido transformaciones, incorporando el sentido de un área de acercamiento entre distintos, de entrelazamiento de diferentes y de anexión de marginales, ${ }^{8}$ generando una viva discusión en los ámbitos académicos, pues la noción de frontera es capaz de impregnar casi cualquier sujeto histórico al que se desee aproximarse. ${ }^{9} \mathrm{Si}$ es posible abordarlas desde perspectivas que pueden ser tanto geopolíticas ${ }^{10}$-en donde las fronteras aparecen sobretodo como lugares de diferenciación entre los estados-, al mismo tiempo es posible apelar a una versión sociológica, ${ }^{11}$ caracterizada por el encuentro y desencuentro de sociedades, movimientos que generan ámbitos híbridos, que son a la vez de mixtura pero también de diversidad, desenvolviéndose con dinámicas propias. En este caso de

6 Morin, Edgar: Ciencia con consciencia, Anthropos, Madrid, 1984, pág. 213.

7 Jackson (ed.), Robert H.: New views of Borderlands History, University of New Mexico Press, Albuquerque, 1998.

8 Ver Gordillo, Gastón y Leguizamón, Juan Martín: El río y la frontera. Movilizaciones aborígenes, obras públicas y MERCOSUR en el Pilcomayo, Editorial Biblos, Buenos Aires, 2002, pág. 15.

9 Esa multiplicidad de acepciones incluye fronteras culturales, étnicas, socioeconómicas, generacionales, artísticas. Ver [en línea] www.oni.escuelas.edu.ar/olimpi98/FronterasCulturales/datos/ frontera.html [Consultado: 27/07/01]. También Higa, Jorge: "La frontera en el cine nacional", Todo es Historia, Buenos Aires, n. ${ }^{\circ}$ 301, agosto de 1992, págs. 24-5.

10 Terrero, Guillermo A.: Geopolítica argentina. Población, fronteras, comunicaciones, antropología, Plus Ultra, Buenos Aires, 1983; Boscovich, Nicolás: Geoestrategia para la integración regional, Ciudad Argentina, Buenos Aires, 1999.

11 Schiavoni, Gabriela: "Las regiones sin historia: apuntes para una sociología de la frontera",

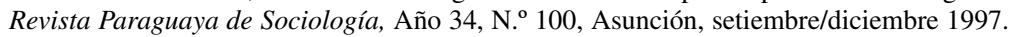


estudio, atendiendo a la peculiar modalidad que la política colonial hispánica legó para pensar la frontera, definiendo territorios a conservar y a defender, ${ }^{12}$ actuando también en función de procesos de expansión y ocupación efectiva, ${ }^{13}$ pretendemos acercar explicaciones de cómo se ejerció el poder y la violencia y que resistencia se manifestó en los espacios fronterizos de la región del Gran Chaco, ${ }^{14}$ al aplicarse medidas para neutralizar a los aborígenes que eran considerados como elementos de disturbio social. ${ }^{15}$ Se hace así una amplia referencia a los efectos de la frontera sobre la vida regional y nacional. ${ }^{16}$

Las fronteras argentino-bolivianas-paraguayas chaquenses se constituyeron en un ámbito de contacto, pero también de rebeldía que se extendió hasta muy entrado el siglo XX, aún cuando los estados nacionales fueron asentando su soberanía y ejercitándola sobre los "paisanos de región"17 como eran los pobladores, indios, pero también blancos y mestizos, de aquellos confines.

\section{El comienzo de la disputa por el Chaco Boreal}

El vasto escenario del Gran Chaco, en el que se suceden llanuras — cubiertas de palmeras y quebrachales - y montes selváticos, sequías e

12 Barros, Claudia y Zusman, Perla: "Nuevas y viejas fronteras, ¿Nuevos y viejos encuentros y desencuentros?", Scripta Nova, N. 69 (50), Barcelona, 1 de agosto de 2000.

13 Clementi, Hebe: La frontera en América. América del Sur. Venezuela-Los países andinos: Ecuador, Perú, Chile, Bolivia. La Guerra del Salitre. 3, Editorial Leviatán, Buenos Aires, 1987.

14 Cuando entrelazamos los conceptos de espacio y de región, nos resulta pertinente apelar a las reflexiones del historiador Heredia, quien reconociendo el toque de audacia de quienes incursionan por estos campos transdisciplinarios, propone "que el espacio es la idea de base a partir de la cual el hombre forma el concepto de región, es decir que es una creación del hombre elaborada a partir de una mirada contemplativa y por tanto subjetiva del medio circundante, esto es de aquel medio del cual cada hombre se siente eje y centro", en Heredia, Edmundo A.: Espacios regionales y etnicidad, Alción Editora, Córdoba, 1999, págs. 46-7

15 Sobre la contención dentro de los límites políticos, ver Caviedes, César N.: "ArgentineChilean Cooperation and Disagreement along the Southern Patagonia Border", en Gallusser, Werner A., in collaboration with Bürgin, Matthias and Leimgruber, Walter: Political Boundaries and Coexistence, Peter Lang, Procedings of the IGU-Symposium, Basle, Switzerland, 24-27 may 1994, pág. 137.

16 Parentini, Luis Carlos: "Surgimiento de la frontera indígena", en Lacoste, Pablo (compilador): Argentina y Chile 500 años de integración, Universidad del Congreso-Universidad Nacional de Cuyo-Universidad de Chile-Universidad Católica Blas Cañas, Mendoza, 1997, pág. 39.

17 Benencia, Roberto y Karasik, Gabriela: "Bolivianos en Buenos Aires: aspectos de su integración laboral y cultural", Estudios Migratorios Latinoamericanos, año 9, N. ${ }^{\circ}$ 27, Buenos Aires, 1994. 
inundaciones, viento cálido del norte y corrientes frías del sur, abundancia de insectos y alimañas, se mantuvo en la penumbra de la historia construida por el hombre blanco. Sus pueblos autóctonos, parafraseando definiciones clásicas, fueron gentes sin pasado, que comenzaron a enredarse en relatos ajenos.

Aquel clima extremo, el enmarañado ambiente, la lucha encarnizada con los aborígenes que lo poblaban, contribuyeron a construir desde los tiempos de la conquista española la imagen de un territorio inhóspito, de difícil supervivencia para quienes no habían nacido allí. Las dificultades para su poblamiento y el arduo proceso de integración a los estados de la Argentina, Bolivia y Paraguay, ahondaron desde principios del siglo XIX, la convicción de que se trataba de una zona atroz e inaccesible. ${ }^{18}$

Dividido desde el punto de vista geográfico en el Chaco Boreal, al norte del río Pilcomayo, el Chaco Central, entre los ríos Pilcomayo y Bermejo, y el Chaco Austral, al sur del río Bermejo, no faltaron los litigios para asegurar la posesión respectiva de las diferentes porciones de aquel territorio para los gobiernos de Buenos Aires, de La Paz y de Asunción. Si la pretensión de dominio sobre el Chaco Austral y Central fue reivindicada por la Argentina - asegurada en 1872 durante la presidencia de Domingo Sarmiento-,${ }^{19}$ la disputa por la región Boreal databa de los albores independentistas. Los poderes estatales que aspiraron históricamente a esa porción, esto es Charcas (Audiencia) y Buenos Aires (virrey), se encontraban situados a enorme distancia, en comparación con la ubicación de Asunción. Para algunos analistas, ello constituyó el decisivo motivo para que, a la postre, Paraguay a pesar de su debilidad pudiera conservar para sí ese Chaco. ${ }^{20} \mathrm{El}$ fallo arbitral del presidente norteamericano R. Hayes concedió a aquel país arrasado por la guerra de la Triple Alianza, la zona comprendida entre el río Pilcomayo y el río Verde. Pero de manera paralela, y apremiada por obtener una vía de acceso hacia el Atlántico después de su derrota en la Guerra del Pacífico, las reclamaciones de Bolivia por la región norte del Chaco se fueron planteando de manera constante y sostenida, haciendo caso omiso de la cuestión dirimida en 1878.

18 Lois, Carla Mariana: "La invención del desierto chaqueño. Una aproximación a las formas de apropiación simbólica de los territorios del Chaco en los tiempos de formación y consolidación del estado nación argentino", Scripta Nova, N. 38, Barcelona, 15 de abril de 1999.

19 Maeder, Ernesto J. A.: Historia del Chaco, Plus Ultra, Buenos Aires, 1997, pág. 91.

20 Assef, Alberto Emilio: Proyección continental de la Argentina. De la Geohistoria a la Geopolítica Nacional, Pleamar, Buenos Aires, 1980, pág. 152. 


\section{Los estados nacionales en el Gran Chaco}

Nominalmente, la república del Paraguay incorporó el territorio a su perfil geográfico, fijando sus límites internacionales al oeste en el río Parapetí y una línea terrestre indefinida, que pasaba en inmediaciones del meridiano 62. ${ }^{21}$ Aprovechando la venta de tierras fiscales que se produjo después de 1870, empresas de capitales argentinos y norteamericanos se establecieron al norte del Chaco, sobre la margen izquierda y derecha del río Paraguay, dedicándose a la explotación de los campos y montes de quebrachos y a la ganadería. Como señaló en sus estudios etnohistóricos sobre el Gran Chaco el antropólogo Métraux, aunque al norte del Pilcomayo la presencia blanca fue poco menos que nula en las primeras décadas del siglo $\mathrm{XX},{ }^{22}$ se fueron constituyendo reducidos núcleos de habitantes, tales como Villa Hayes, ${ }^{23}$ Olimpo y Bahía Negra, más las poblaciones de obreros de los establecimientos industriales de Puerto Galileo, Puerto Casado, Puerto Sastre, Puerto María, Puerto Pinasco y otras menores. Además unos treinta mil indios en estado de independencia (condición llamada por algunos, salvaje) se movilizaban por el Chaco Boreal, sumando ya desde principios de la centuria alrededor de unas sesenta mil personas que habitaban la región. No obstante, en vísperas de la guerra con Bolivia, el Chaco no tenía "núcleos de población ni producción alguna de alimentos que no fuera una incipiente ganadería en la región aledaña al río Paraguay, sin caminos y sobre todo sin agua". ${ }^{24}$ Mientras tanto, en el extremo este del Chaco misiones franciscanas se habían fundado al sur de Santa Cruz de la Sierra, a las que se fueron sumando algunos establecimientos comerciales y centros ganaderos diseminados hasta Villa Montes —en el Pilcomayo-, Yacuiba y Tartagal, que llevaban a la Argentina animales para obtener a cambio abastecimientos..$^{25}$

21 La República del Paraguay. Un siglo de vida nacional.1811-1911, Asunción, 1912, pág. 57.

22 Métraux, Alfred: Etnografía del Chaco, El Lector, Asunción, 1996, pág. 24.

23 Pérez Acosta, Juan F., señalaba en: Núcleos culturales del Paraguay contemporáneo. Confraternidad y cultura. Homenaje al Instituto Paraguayo en su cincuentenario (1895-10 de julio1945), Buenos Aires, 1959, pág. 76, que ya después de 1873, "algunos paraguayos pasaron [entonces] a Villa Occidental (después Villa Hayes) que estaba a la sazón en poder de las fuerzas argentinas, cuando aún no existía Clorinda y tampoco Formosa".

24 Ashwell, Washington: Historia económica del Paraguay. Colapso y abandono del sistema liberal, 1923-1946, Tomo II, Ediciones y Arte S.R.L., Asunción, 1996, pág. 207.

25 Fifer, J. Valerie: Bolivia. Territorio, Situación y Política, desde 1825, Editorial Francisco de Aguirre, Santiago-Buenos Aires, 1976, pág. 293. 
Bajo la consigna de bolivianizar el espacio chaquense, ${ }^{26} \mathrm{La}$ Paz inició la política de penetración en el Chaco Boreal a principios del siglo XX, con la fundación sobre el río Pilcomayo de fortines y la construcción de un camino en demanda de Bahía Negra en 1905, estrategia a la que el gobierno de Asunción sólo había respondido con la intensificación de la ocupación civil que produjeron las industrias agrícolas.

En tanto que la Argentina fue robusteciendo su vinculación política y su dominio económico en el Paraguay a través de empresas que ligaban los establecimientos del Chaco, con los directorios establecidos en Asunción, Rosario y Buenos Aires, y a través de compañías de transportes fluviales, la relación con Bolivia era mucho menos estrecha. Como señala Fifer, recién a partir de 1888 se fueron adoptando provisionalmente los límites entre los dos países en casi completa ignorancia de la geografía: en 1904 el gobierno de Buenos Aires accedió a transferir Yacuiba, capital de la provincia boliviana del Gran Chaco que en las delimitaciones había quedado situada en el lado argentino, a lo cual siguieron no pocas incidencias bilaterales que incluyeron disputas, ruptura de relaciones y largas negociaciones de límites que se prolongaron hasta la década del veinte. ${ }^{27}$

El gobierno paraguayo manifestó en más de una ocasión su deseo de encontrar apoyo de parte de la Argentina en su litigio fronterizo con Bolivia. Ante ello, los gobiernos de Buenos Aires y también su jerarquía militar siguieron atentamente las aspiraciones bolivianas, y el respaldo que pudiera otorgarle el Brasil a su posición, de obtener territorio y puertos sobre el río Paraguay, considerando que su apoyo político y material a los paraguayos era necesario, porque librado a sus medios Asunción tendría que ceder, dadas sus condiciones de inferioridad económica y logística, afectándose así los importantes capitales e intereses argentinos arraigados en la región del Chaco.

Aquel contencioso coincidía con los esfuerzos argentinos por cumplir el objetivo de avanzar hacia los confines del país, alcanzando el río Pilcomayo, ${ }^{28}$ y ocupando de esa manera, las áreas de la frontera con

26 Bejarano, Ramón César: Fortines paraguayos y bolivianos.1905-1932, Asunción, 1984, pág. 21.

27 Fifer: Bolivia..., pág. 295.

28 El Pilcomayo, que nace en Bolivia en la provincia de Tarija, se interna bañando el Chaco para desembocar en el río Paraguay en las inmediaciones de Asunción. El río se transformó en un dilatado espacio fronterizo, experimentando constantes quiebres en su cauce, diluyéndose en esteros y desembocando en bañados. Ver Machuca, Christian Matías Machuca: "La problemática del río Pilcomayo", Boletín del Centro Naval, 795, Buenos Aires, 1998-99; Gordillo, Gastón: “Canales para 
Paraguay y Bolivia y la frontera interior. ${ }^{29}$ Sin embargo, las acciones emprendidas para superar la ausencia de actividad económica en la región norteña fueron de lenta ejecución, motivadas por los mayores intereses de todo tipo que habían llevado a privilegiar la ocupación del territorio pampeano y patagónico ${ }^{30}$ y luego a mantenerse ocupados en esos desarrollos más rendidores, y en relacionarse con el poderoso vecino de tras los Andes, Chile. Creados los territorios nacionales de Formosa, Chaco y Misiones, los regimientos instalaron sus jefaturas sobre las proyectadas líneas férreas de Formosa-Embarcación y de Barranqueras-Metán y sobre el río Bermejo y el Pilcomayo. Los comandos se establecieron en las denominadas Grandes Guardias con efectivos variables y patrullas de avanzada, levantándose fortines que arrancaban en el noroeste desde Jujuy hasta llegar a la ribera del Paraná, cerca de Esquina en Corrientes. Ello otorgó una mínima seguridad contra los asaltos de indígenas, atrayendo hacendados y nuevos pobladores blancos, mientras los efectivos militares construían casi mil kilómetros de líneas telegráficas, cortando y colocando postes, abriendo picadas en los montes, arreglando caminos y tendiendo precarios puentes que comunicaban entre sí a los fortines. ${ }^{31}$

En 1917, organizado el primer regimiento de Gendarmería de línea de la Argentina, este pasó a cubrir la frontera, especialmente de Formosa con el Paraguay y de Salta con Bolivia, "región que constituía una "zona caliente" por la existencia de bandoleros y aborígenes que desalojados de sus antiguos reductos, se alzaban y atacaban los establecimientos y asentamientos de los colonos". ${ }^{32}$ Sin definir la soberanía en el Chaco Boreal, los militares argentinos intentaban detener las incursiones de los indígenas que guarnecidos en la zona boliviana o paraguaya periódicamente asolaban el espacio ribereño. Los destacamentos se desempeñaban también como centros policiales, de sanidad de primera escolarización y como estafetas de

un río indómito. Frontera, Estado y utopías aborígenes en el noroeste de Formosa”, en Grimson, Alejandro (compilador): Fronteras, naciones e identidades. La periferia como centro, Ciccus-La Crujía, Buenos Aires, 2000, pág. 253.

29 Ver Auza, Néstor Tomás: "La ocupación del espacio vacío: de la frontera interior a la frontera exterior. 1876-1910", en Ferrari, Gustavo-Gallo, Ezequiel (compiladores): La Argentina del Ochenta al Centenario, Buenos Aires, 1980, pág. 79 y ss..

30 Menéndez, Rómulo Félix: Las conquistas territoriales argentinas, Editorial Dunken, Buenos Aires, 1998, pág. 365.

31 Torino, Esther María-Figueroa de Freytes, Eulalia: "El C. 5 en la integración territorial del Noroeste argentino", Primer Seminario de Historia del Chaco, E.U.C.A.S.A., Salta, 1982, pág. 278 y ss.

32 Gendarmería Nacional Argentina. 60 años, Buenos Aires, 1998, pág. 26. 
correo y juzgados de paz, tras el objetivo de "nacionalización" de la frontera, donde la pertenencia de los habitantes, como de los inmigrantes a los diferentes estados, era endeble, constituyendo una realidad espacial difusa en donde existían ambigüedades e incertidumbres, ${ }^{33}$ que se prolongarían por décadas. Por esa razón, la celebración de las fiestas, la difusión de las canciones y la profusión de los símbolos patrios también formaban parte de las actividades propias de las guarniciones militares. Otro propósito a perseguir, fue el de incorporar aquellas regiones como potenciales contribuyentes de rentas aduaneras para las arcas estatales, controlando también la ilegalidad y el contrabando. ${ }^{34}$

La incorporación de ese extendido paisaje fronterizo a los estados nacionales aparece como un proceso asimétrico en la relación argentinoparaguaya-boliviana. Si los gobiernos de Buenos Aires propulsaron la militarización de la frontera, favorecieron tanto las misiones religiosas como la reducción de los indígenas y la colonización, el Paraguay dejará más libradas las tierras chaquenses a la ocupación y explotación sin mayores limitaciones de los intereses de capitales extranjeros y luego a la experiencia aislacionista de las colonias mennonitas, que desde fines de 1920 encontraron su viabilidad comunitaria en emprendimientos agroganaderos y forestales. Bolivia también apenas avanzará con modestas instalaciones militares, hasta que el descubrimiento de petróleo en las estribaciones de los Andes y las prospecciones que realizó la empresa Standard Oil de New Jersey en 1920, acelerará sus demandas y sus deseos de mejorar las comunicaciones en la región.

\section{Los caminos en el Gran Chaco}

Para la Argentina, su frontera norte, tanto en el flanco este como oeste presentaba las características de un páramo succionado desde el interior del Cono Sur. ${ }^{35}$ Jujuy y Salta sufrían un estado de pobreza y estancamiento notorio, siendo grave su incomunicación con el resto del territorio nacional, por falta de transporte en algunos casos y también por el costo de los

33 Schiavoni: "Las regiones sin historia...”, pág. 262.

34 Hevilla, María Cristina: "El Estado innovador: estrategias de control y contacto en la frontera", Scripta Nova, N. 69 (51), Barcelona, 1 de agosto de 2000.

35 Ver Heredia, Edmundo: “Existe el Cono Sur?”, en Rapoport, Mario y Cervo, Amado Luiz (compiladores): El Cono Sur. Una historia común, FCE, Buenos Aires, 2001, págs. 323-37. 
fletes ferroviarios, y con los países vecinos donde estuvieron en el pasado sus mercados tradicionales, habiéndose reducido en especial su activo comercio con Bolivia. Aunque en 1882 el ministro de Relaciones Exteriores de la Argentina Victorino de la Plaza había firmado con el gobierno de La Paz un primer tratado con el propósito de vincular ambos países con líneas férreas, se sucederían varios convenios binacionales hasta que los ferrocarriles argentinos se prolongaran para conectarse con Bolivia.

Salta, dependiente de una economía agropastoril pero con diversidad de recursos, en especial su región chaquense, estuvo imposibilitada de acceder al mercado nacional ${ }^{36}$ en tanto no se terminó la construcción de los ramales ferroviarios de Embarcación a Formosa y de la estación Metán al puerto Barranqueras, en el Territorio del Chaco, tendido que fue gestionado por los poderes políticos salteños y que prometió una puerta de salida para la producción hacia el río Paraná, materializando la vinculación con el este de la Argentina. La línea de Embarcación debía perfeccionarse llevándola hasta Yacuiba con lo cual se contribuiría de manera efectiva a la integración con Bolivia. ${ }^{37}$ En tanto, el ramal del Central Norte, llegó algo tarde cuando ya se había producido el despegue agroindustrial de la región tucumana con los grandes ingenios azucareros. ${ }^{38}$

Aquellos ferrocarriles argentinos que arribaron al noroeste, se ramificaron para seguir las dos sendas tradicionales del comercio con el sur boliviano. Al oeste corría por Humahuaca hasta el límite en La Quiaca, aunque la prolongación en territorio boliviano fue demorada hasta la década del veinte. El enlace transcontinental dejó entonces a $\mathrm{La} \mathrm{Paz}$ a sólo tres o cuatro días de Buenos Aires (línea La Paz-Potosí-San Salvador de Jujuy), ${ }^{39}$ mientras la vía férrea también llegaba hasta la localidad salteña de Tartagal. La segunda extensión ferroviaria siguió la ruta de los faldeos de los Andes bordeando la región del Chaco. En 1908 comenzó la construcción del

36 Bazán, Armando Raúl: El Noroeste y la Argentina contemporánea (1853-1992), Plus Ultra, Buenos Aires, 1992, pág. 338.

37 Ibídem, pág. 353.

38 Teruel, Ana A.: "Cuestiones relativas a la incorporación de espacios fronterizos al EstadoNación. Chaco occidental, 1862-1911”, en Teruel, Ana, Lacarrieu, Mónica, Jerez, Omar: Fronteras, Ciudades y Estado, Alción Editoria, Córdoba, 2002, Tomo I.

39 Horacio Carrillo, que fue el representante argentino que firmó el convenio en La Paz, había sido gobernador de Jujuy entre 1918-1922, por tanto conocía bien las necesidades de la región. Ver Carrillo, Horacio: El ferrocarril al Oriente boliviano. (Algunos antecedentes de la Convención. Notas personales), Coni, Buenos Aires, 1922. 
ferrocarril desde Formosa a Embarcación, lo cual atrajo una gran afluencia de trabajadores. El tendido constituyó una hazaña debido a lo brutal de la región que debía atravesar, donde no faltaron el ataque de indios hostiles, bandoleros, fieras, insectos, calor y la escasez de agua. El obstáculo mayor que se presentó fue el gran estero Pirané, aunque también el hacer picadas en los bosques insumió mucho tiempo y esfuerzo, pues se debían hachar colosales cimientos de madera dura. La construcción continuó hasta Las Lomitas, donde se estancó en 1915, para continuar hacia su meta final en diciembre de 1930. El saldo de muertos y heridos fue considerable, no resulta exagerado decir que "la vía quedó jalonada de cruces". ${ }^{40}$ Aquella línea daría grandes ingresos al estado nacional, debido mayormente al transporte del petróleo.

En septiembre de 1925, la Argentina y Bolivia habían suscripto un convenio complementario de vías de comunicación con el objetivo de fomentar el intercambio comercial, facilitar la salida del productos y acercar las grandes vías fluviales. El gobierno de Marcelo T. de Alvear recogía así preocupaciones de orden militar, señaladas especialmente por el Estado Mayor General de la Armada en el sentido de controlar las rutas comerciales de Bolivia y Paraguay, adelantándose a los propósitos de desviar las respectivas producciones por territorios chilenos y brasileños. ${ }^{41}$

A lo largo de la década del treinta se irían acordando los términos para la construcción de la prolongación hasta Yacuiba en dirección al Oriente boliviano y para la prospección de pozos petrolíferos en el área de Sanandita-Madrejones en el lado boliviano, planificándose oleoductos desde esos campos y desde el distrito del Bermejo, mientras el petróleo boliviano iría a la Argentina en retorno de pago. Pero el proyecto se dilató hasta el fin de la guerra del Chaco, falta de entendimiento de ambos gobiernos que tuvo variadas explicaciones, además de las más obvias y contundentes que implicaron las operaciones bélicas desplegadas: por un lado, la no industrializada región del Altiplano no podía competir con el menor costo y la mayor calidad de los productos manufacturados provenientes del mercado argentino, por lo que había temores para abrir las vías a una exportación que beneficiaria sobre todo al área de Santa Cruz de la Sierra. pág. 106

40 Cecotto, Alejandro: Historia de Formosa y episodios atinentes, Formosa, 1957,

41 Armada Nacional. Departamento de Estudios Históricos Navales, Buenos Aires (en adelante DEHN), Donación C.A. (RE) Scasso L., Caja 4, Legajo 2, carpeta 58, Buenos Aires, 2 de diciembre de 1925, fdo., Carlos G. Daireaux, contralmirante, Jefe del Estado Mayor General. 
Existieron en Bolivia, pulsiones contrarias a la vinculación con la Argentina, que prefirieron postergar estas concreciones hasta que las comunicaciones entre el Oriente y el Altiplano fueran perfeccionadas, por temor a favorecer un desarrollo autónomo o ligado al Plata, de una región que había manifestado signos de separatismo. Además las autoridades de Buenos Aires adoptaron medidas que afectaron la economía boliviana y alimentaron un sentimiento antiargentino que tenía no pocos cultores en La Paz. Entre ellas figuraban la elevación de los aranceles sobre las exportaciones de petróleo boliviano en 1927 y la negativa a garantizar el privilegio de la construcción de oleoductos a la Standard Oil. ${ }^{42}$

Hacia el este, la frontera del Pilcomayo, comenzó a ser efectivamente ocupada por la Argentina recién después de las campañas desarrolladas con un ritmo ofensivo más o menos constante entre 1870-1917, en un proceso que se manifestó a través de la confluencia de ese avance militar y de la colonización agrícola-ganadera ${ }^{43}$ Contrariamente, la debilidad y la carencia de recursos de un Paraguay empobrecido y devastado, con mínimas posibilidades de capacidad de acción impedía una paralela ocupación y transformación de la otra banda del Pilcomayo. Entonces, la Argentina era casi el único mercado para las exportaciones paraguayas, con un tráfico comercial que se efectuaba por vía fluvial, dificultado por las escasas facilidades portuarias, así como las bajantes de los ríos. En cuanto a la vía férrea, recién en 1913 quedaría terminado el enlace entre la línea Asunción-Villa Encarnación con el ferrocarril argentino de Posadas, Territorio de Misiones, pasando a funcionar como la única ruta no fluvial para el comercio entre la Argentina y el Paraguay.

Distintas parcialidades indígenas se seguían desplazando desde el Alto Pilcomayo, en la frontera argentino-boliviana, hasta su desembocadura, en los límites argentino-paraguayos. La carencia de una noción del espacio abstracto entre los aborígenes podría ayudar a explicar parte de su

42 Ver Mosconi, Enrique: La batalla del petróleo. YPF y las empresas extranjeras, Buenos Aires, 1957, pág. 103-55. También Mayo, C.A., Andino, O.R. y García Molina, F.: La diplomacia del petróleo (1916-1930), C.E.A.L., Buenos Aires, 1983, y Solberg, Carl E.: Petróleo y nacionalismo en la Argentina, Hyspamerica, Buenos Aires, 1986.

43 Beck, Hugo Humberto: Relaciones entre blancos e indios en los territorios nacionales de Chaco y Formosa. 1885-1950, Cuadernos de Geohistoria Regional-Instituto de Investigaciones Geohistóricas, Resistencia, 1994. Ver también Trinchero, Héctor Hugo: Los dominios del demonio, pág. 140, sobre lo que denomina "El despliegue corporativo del Ejército", y Lagos, Marcelo: "Estado y cuestión indígena. Gran Chaco 1870-1920”, en Teruel, Ana, Lacarrieu, Mónica, Jerez, Omar: Fronteras... . 
rechazo a constreñirse a los límites estatales, ${ }^{44}$ indios chaquenses que a diferencia de los pampeanos, no formaron una fuerza bélica medianamente organizada, actuando a través de golpes de mano sorpresivos sobre poblaciones mal defendidas o sobre núcleos de tropas muy inferiores en número. ${ }^{45}$ Además, la introducción o explotación de cultivos susceptibles de ser exportados, habían promovido la ocupación del amplio espacio chaqueño y la captación forzosa de las parcialidades aborígenes para contar con los medios humanos imprescindibles para la extracción de los recursos naturales, siendo un factor decisivo para el desarrollo de las agroindustrias del norte argentino, proporcionando una mano de obra abundante y barata. ${ }^{46}$ Los escenarios fueron sobretodo los ingenios azucareros de Salta y Jujuy, y algunos de Formosa, los obrajes para desmontar quebrachales, producir durmientes y extraer tanino, las cosechas de algodón, la construcción de caminos, telégrafos y ferrocarriles, la ganadería, los yerbales. Los gobiernos de la Argentina trataron de asegurar la disponibilidad de la labor indígena para el desarrollo económico del área, para lo cual se establecieron las reducciones, aunque también se aseguró el reclutamiento desde sus mismas tolderías. La creciente limitación de sus áreas de caza y pesca situaban a los indios ante la disyuntiva del hambre, por lo cual los más dóciles y los más necesitados comenzaron a aceptar aquel requerimiento compulsivo de contratistas y de las fuerzas militares que vigilaban la efectividad de los desplazamientos, creando una convivencia que aunque abusiva, despertó expectativas de producir una paulatina integración con el ele-

44 En el estudio publicado en el Primer Seminario de Historia del Chaco..., página 392 y ss., organizado por la Facultad de Artes y Ciencias de la Universidad Católica de Salta, que lleva por título "Lenguas aborígenes del Chaco salteño", se señala: "Con respecto a la idea de espacio tampoco existe la noción del espacio abstracto en el que se dan las nociones de arriba, abajo, adentro, afuera, cerca, lejos. Todo se relaciona a un espacio físico concreto, susceptible de referencias reales. Espacio, tiempo y cantidad forman un mundo cuyo horizonte vital da a los hablantes de estas lenguas una singular estructura mental que se expresa también en una singular estructura lingüística. Esta visión cambia a medida que las comunidades se relacionan con los grandes centros de población y se van suplantando elementos. En algunos casos se llega a un total desconcierto frente a una realidad difícil de asimilar". Ver también Tovar, Antonio: Relatos y diálogos de los matacos, Ediciones Cultura Hispánica, Madrid, 1981.

45 Ver Cordeau, Edgardo-Siffredi, Alejandra: De la algarroba al algodón: movimiento mesiánico de los guaycurú, Juárez Editor S.A., Buenos Aires, 1971, pág. 45; Depetris, Juan Carlos: "Confinamiento de pampas y ranqueles en los ingenios de Tucumán", Todo es Historia, N. 295 , Buenos Aires, enero 1992, pág. 68.

46 Ver Teruel, Ana A. (comp.): Población y trabajo en el Noroeste argentino. Siglos XVIII y XIX, UNIR-UNJu, Jujuy, 1995; Bolsi, Alfredo S.C.: Apuntes para la geografía del nordeste argentino (Un ejemplo de regresión regional), Cuadernos de Geohistoria Regional, Resistencia, 1985. 
mento criollo. Pero esos indígenas explotados, formando grupos agotados por el hambre, la persecución y el cansancio, continuaban siendo potencialmente agresivos. ${ }^{47}$

\section{Los habitantes de la región y la Guerra en el Chaco, 1932-1935}

Un período de intensa actividad militar en el Gran Chaco tuvo lugar cuando la guerra estalló entre el Paraguay y Bolivia en $1932 .{ }^{48}$ Gran parte del Chaco quedó entonces erizado de fortines: los productos de la confrontación boliviano-paraguaya, y los argentinos que vigilaban su frontera, mientras tanto, la población indígena recibía el enorme impacto de las acciones bélicas, de las movilizaciones y del contacto exigente de los militares paraguayos, bolivianos y argentinos. Antes del conflicto, los grupos tribales que poblaban el Chaco habían sido incorporados en alguna proporción por el ejército boliviano y por el paraguayo desempeñando tareas tales como rastrear el monte, fabricar refugios en los árboles, transportar canoas en el Pilcomayo, hacer de guías y espías, abastecer con sus productos a las tropas ${ }^{49}$ Cuando Bolivia comenzó la ofensiva contra Paraguay, indios quechuas y aymarás fueron reclutados para pelear en el frente, siendo enviados a una extraña y hostil región para morir por algo de lo que eran

47 Schaller, Enrique C.: La colonización en el territorio nacional del Chaco en el período 1869-1921, Cuadernos de Geohistoria Regional N. 12 , Instituto de Investigaciones Geohistóricas, Resistencia, 1986, pág. 142.

48 Perdida la salida al mar tras su derrota en la guerra del Pacífico, después del protocolo chileno-peruano de 1929 que arregló las controversias en torno a las ciudades de Tacna y Arica, Bolivia experimentó el sentimiento nacional de un estado que se consideraba injustamente desmembrado por todos sus vecinos. En aquel contexto crítico el gobierno de Daniel Salamanca tomó la decisión de anteponer los problemas internos de su país al empeño de una audaz acción militar contra el Paraguay: en junio de 1932, después de continuas escaramuzas entre los fortines chaquenses, una incursión boliviana al Fuerte Pitiantuta señaló el comienzo de las hostilidades. Las armas paraguayas llevaron la ventaja, aunque no pudieron culminar su campaña victoriosa con la toma de los yacimientos petrolíferos y las ciudades de Santa Cruz de la Sierra y Tarija, ya en las estribaciones andinas. Bajo los auspicios de un grupo mediador americano, se suscribió en Buenos Aires el 12 de junio de 1935 un protocolo de paz, fijándose el cese del fuego e inaugurándose las negociaciones. Después de arduas discusiones y amenazas de reanudar las hostilidades, se arribó al tratado definitivo en julio de 1938: aunque Bolivia perdió la mayoría del Chaco Boreal, conservó el control de sus áreas petroleras al obtener una retirada paraguaya en el oeste chaquense, sin pagar reparaciones económicas.

49 Ver Arze Aguirre, René Danilo: Guerra y conflictos sociales. El caso rural boliviano durante la campaña del Chaco, Ceres, La Paz, 1987, págs. 80-82. También Hirsch, Silvia María: “The Capitanía of the Izoso: The Struggle for Political Autonomy among the Guaraní Indians of Eastern Bolivia", en Miller, Elmer S.: Peoples of the Gran Chaco, Bergin \& Garvey, Wesport, Coon.-London, 1999, pág. 64 y ss. 
ignorantes, mientras los aborígenes de las tierras bajas bolivianas fueron poco requeridos como soldados, por el rumor de que eran potenciales aliados de los paraguayos..$^{50} \mathrm{La}$ tropa mestiza de los paraguayos, gente que conocía el área y sabía mejor como subsistir allí, superó a los indios andinos. No obstante ambos ejércitos sufrieron el problema de las deserciones de sus soldados — aunque en menor grado el paraguayo-llegando a preocupar a los comandantes, en especial cuando las tropas estaban cerca del límite con la Argentina. ${ }^{51}$ Cuanto que muchos lograban huir sin ser atrapados, los fugitivos eran internados y sometidos a cuarentenas sanitarias con el propósito algo iluso de evitar que introdujesen al sur del Pilcomayo enfermedades.

Cuando las hostilidades terminaron, los indios chaquenses de la Argentina, de Paraguay y de Bolivia fueron de nuevo habilitados para vagar por la región, recolectando, cazando y pescando, aunque la ocupación de las tierras por las que habían litigado los aparatos estatales llevarían a un último arrinconamiento de los primigenios habitantes. Los cambios habían sido esta vez demasiados. Los militares batieron el territorio por años, tiempo durante el cual los indios fueron movidos de un lado para otro, diezmados por epidemias y acorralados en nuevos asentamientos. Se habían producido transformaciones en la organización social, introduciéndose la economía monetaria que tendía a reemplazar al trueque, creando la necesidad de provisiones y bienes para consumir, tales como bicicletas, radios, kerosene, ropas occidentales, armas, así como nuevos modos de enfrentar el mundo y la vida. Algunos grupos de indios se habían ido armando con elementos y rezagos de guerra abandonados por el ejército de Bolivia en el campo de batalla, a medida que avanzaban los paraguayos. Cuando los bolivianos del altiplano se perdían en el monte chaqueño, muriendo muchos de ellos de sed, los indios apostados en las aguadas, en ocasiones los remataban para robarles la ropa y las armas: $: 52$ aquellos "indios matacos hicieron la guerra por su cuenta". ${ }^{53}$

50 Alvarsson, Jan-Ake: The Mataco of the Gran Chaco. An Ethnographic Account of change and continuity in Mataco Socio-Economic Organization, Acta Universitatis Upsaliensis, Uppsala, 1988, pág. 29.

51 Chiavenato, Julio José: La Guerra del Chaco. Petróleo, Carlos Schauman editor, Asunción, 1989, pág. 157.

52 Sánchez Bonifato, César L.: La última Guerra en Sudamérica, Editorial Korrigan, Buenos Aires, 1974, pág. 15.

53 Bande, Manuel: Fortín La Soledad, Santa Fe, 1994, pág. 70. 
Desde Buenos Aires se enviaban distinciones y señales de identidad perdurables: sólo el orden porteño podía hacerse presente en aquellas regiones para impulsar su desarrollo, terminar de conquistar el territorio y protegerlo de las incursiones de los indios que sin ciudadanía se refugiaban allende el Pilcomayo o en las espesuras de los bosques. El Ministerio de Guerra de Argentina afirmaría entonces que el destacamento Formosa había establecido el respeto de la frontera, "pues ésta, hasta su llegada, era atravesada impunemente por elementos extraños que arreaban las haciendas y cometían toda clase de atropellos y desmanes contra los pobladores", y además "consolidó la soberanía argentina, en una parte del territorio nacional donde el $90 \%$ de pobladores eran extranjeros, en su mayoría paraguayos y bolivianos". ${ }^{4}$

\section{La ruta de los fortines}

Mientras perduraron las tensiones bélicas en los confines chaquenses, en especial a todo lo largo de la década del treinta, la cohabitación de sus pobladores fue muy intensa y demandante. En tanto que los oficiales argentinos casados podían asentarse en sus destinos militares con toda su familia, los soldados, voluntarios o castigados con recargos de servicios vivían "casi todos amancebados o en concubinato con indias y paraguayas del monte, que era casi lo mismo, cargados de hijos propios y ajenos, sin que la distinción les importara mucho". ${ }^{55}$ Mientras las parcialidades indígenas no renunciaban a sus propias rivalidades, sosteniendo periódicos choques por la posesión de esteros y lagunas, otros actuaban como prácticos, o siguieron haciendo trabajos temporarios para los puesteros y comerciantes que abastecían los fortines, en tanto que los indios desertores, identificados como tales al huir vestidos con ropas de soldados y armados, eran batidos por los pelotones montados desde los fortines argentinos. Los deficientemente señalizados límites nacionales se cruzaban con espontaneidad, ya fuera en canoa o atravesando la selva a lomo de bueyes y mulas, en territorios donde los caminos desaparecían. En medio de imponentes palmares y grandes montes, pero ocupados de insectos, lodos pestilentes y animales fieros, argentinos, paraguayos y bolivianos se visitaban, cultivando una

54 República Argentina, Memoria del Ministerio de Guerra. Presentada al Honorable Congreso de la Nación. 1932-1933, Buenos Aires, 1933, pág. 107.

55 Bande: Fortín La Soledad..., pág. 60. También Golpe, Néstor L.: Calvario y muerte. Revisión histórica militar. Narraciones fortineras. 1917-1938, Buenos Aires, 1970. 
costumbre tradicional "una galantería fronteriza ...entre quien las hace y el que las retribuye, dado que los fortines están ahicito, se recorren ida y vuelta, unas cien patéticas leguitas", aunque en épocas de crecientes quedaban incomunicados. Asomarse al Pilcomayo era necesario para todos, ya para higienizarse o para recurrir a la pesca en procura de paliar el hambre, en busca de los bagres, de los dorados, de los pacú.

En la caótica distribución de fortines, ${ }^{56}$ entenderse requería cierta destreza: si los soldados paraguayos "hablaban el guaraní, el mismo idioma que los indios de Formosa, intercalando el castellano para hacerse entender", se podía advertir que en el "Chaco hay poliglotas a pesar de no haber academias de idiomas. Algunos de estos pobladores, verdaderos aventureros de las fronteras, hablan castellano, guaraní, pilagá, mataco y quechua, lenguas que tienen entre sí el parecido del castellano con el chino". ${ }^{57}$

\section{Proyectos y políticas modernizadoras sobre el Gran Chaco al fin de la Guerra}

Durante la guerra, el respaldo material decisivo otorgado por la Argentina al Paraguay, que por fuerza fue mantenido oculto, se había convertido en una circunstancia en extremo positiva para el rumbo de la política de colaboración. Pero el gobierno de Buenos Aires persistió en su voluntad de no perder a Bolivia como escenario de su ascendiente, preocupación que se hizo especialmente notable cuando cesaron las hostilidades y comenzó a negociarse la paz. Si los planes económicos para vincularse con la zona de Santa Cruz de la Sierra, aprovechando en especial su potencial petrolífero, venían de tiempo atrás, acuciaba sacar de su retraso a las provincias y territorios del norte argentino, ${ }^{58}$ que no se habían visto

56 Joy, Juan Carlos: Los fortines de la guerra. Toponimia chaqueña, Editora Estudio Gráfico, Asunción, 1992.

57 Da Rocha, Alberto: Tierra de esteros. Relatos de los fortines chaqueños, Buenos Aires, 1937, pág. 78.

58 Como muestra de esa postergación, la Dirección General de Sanidad del Ejército advertía al analizar el período 1928-37, las precarias condiciones físicas de los jóvenes de veinte años provenientes de las regiones norteñas del país que se presentaban a cumplir con el servicio militar obligatorio. Las razones radicaban en el enorme pauperismo, el alcoholismo y la costumbre de mascar coca a que se recurría para paliar el hambre que reinaba en aquellos territorios y provincias; males que eran agravados por las enfermedades endémicas que azotaban a las zonas limítrofes con Paraguay y Bolivia. República Argentina, Memoria del Ministerio de Guerra. Presentada al Honorable Congreso de la Nación. 1937-1938, Buenos Aires, 1938, págs. 48-9. 
beneficiados con las herramientas que desarrollaron vertiginosamente la región de la pampa húmeda, postergando emprendimientos, obras y proyectos de colonización e inmigración. El objetivo de desactivar el conflicto entre Bolivia y Paraguay en su frontera chaqueña llevó a la Argentina a estudiar sus causas y a razonar que la salida hacia el oeste de Bolivia, tradicionalmente controlada por Chile, lo era de manera tan efectiva por las condiciones geográficas, que la búsqueda en el este de la salvadora comunicación directa con el exterior no ofrecía una vía equivalente para el Altiplano. Por tanto, la influencia debía más bien concentrarse en desarrollar el Oriente, cuyo sur sufría de un gran aislamiento. La comunicación con el exterior por puertos bolivianos instalados sobre el río Paraguay que se había pretendido con la guerra, por exigir la travesía de centenares de kilómetros de terrenos anegadizos, cubiertos de enmarañados bosques, donde un camino era tan difícil de construir como de conservar, no podía repercutir sobre las operaciones de importación y exportación de la Bolivia del altiplano, especulaban desde Buenos Aires. ${ }^{59}$ En cambio, la producción de la Bolivia chaqueña, desde el valle de Santa Cruz a Yacuiba, podía acceder a vías férreas argentinas capaces de conducir los productos a los puertos de Formosa, Barranqueras, Santa Fe, y si se deseaba, directamente hasta los de Rosario y Buenos Aires. Se creía haber acercado ya un principio de solución a través de la línea férrea que había llevado desde Jujuy hasta La Quiaca, proporcionándole otra salida e incluyéndola en su esfera de influencia. Se preveía que la terminación de la línea de Metán a Barranqueras podía permitir derivar hasta ese puerto sobre el Paraná, la exportación de minerales de Bolivia, acortándose la distancia a recorrer en ferrocarril y por lo tanto las tarifas. Aquel fue el pensamiento que llevó a Argentina a ajustar en septiembre de 1937 la convención sobre el estudio de un ferrocarril que ligaría Santa Cruz con Yacuiba.

Interesado por los ofrecimientos de La Paz, que aspiraba a conservar el control de las áreas petroleras en la negociación de la paz del Chaco, el gobierno de Buenos Aires había comenzado también en octubre de 1936 conversaciones para realizar operaciones petrolíferas en el Oriente. No obstante, en el mismo mes el presidente boliviano Toro dio instrucciones para negociar proyectos conjuntos con el Brasil, considerándose que si la Argentina podía aprovechar los yacimientos del sur, Brasil podía hacer

59 Archivo del Ministerio de Relaciones Exteriores, Comercio Internacional y Culto de la República Argentina, Buenos Aires (en adelante AMREA), Bolivia-Paraguay, 1935-1937, Caja 23, "La cuestión del Chaco y los problemas económicos de Bolivia". 
otro tanto con los del centro y norte. En Buenos Aires estaban convencidos que el petróleo boliviano, debido a su mediterraneidad, no tendría más valor que el que pudiera darle en el futuro el capital argentino, contando a su favor con las destilerías existentes en Salta. En tanto, Brasil también prometía una salida atlántica a través de la construcción del ferrocarril Santa Cruz de la Sierra-Corumbá-Santos. Los gobiernos de Río de Janeiro habían advertido que el estado argentino estaba llevando adelante lo que llamaba una "magnífica expansión", a través del desarrollo de sus vinculaciones regionales y del fomento de las comunicaciones terrestres y fluviales por líneas interiores. ${ }^{60}$ Desde Tartagal el ferrocarril progresó hasta Pocitos, en la frontera argentina al sur de Yacuiba, ${ }^{61}$ pero un nuevo impulso para la ejecución de la obra se daría cuando estalló la Guerra Mundial, al aumentar la necesidad de combustibles, en la creencia que los yacimientos de Sanandita y el Bermejo que habían sido estudiados por técnicos argentinos con vistas a la financiación de la proyectada línea férrea, podían ser una importante fuente de abastecimientos. En setiembre de 1942 los presidentes Enrique Peñaranda y Ramón Castillo asistieron a la colocación del primer durmiente de las obras en construcción en la zona fronteriza entre Pocitos y Yacuiba. Creadas las comisiones mixtas de trabajo que dieron lugar a los estudios del terreno entre Yacuiba y Santa Cruz, se tropezó con no pocas dificultades al darse comienzo a los trabajos prospectivos: falta de equipos, carencia de experiencia del personal boliviano, obstáculos para trasponer los límites fronterizos, dificultades para obtener peones, desinteligencias con los destacamentos militares, escasez de fondos del gobierno de La Paz que se debatía en medio de serios problemas políticos y económicos, con la liquidación de la guerra del Chaco. Iniciar los estudios en plena época de tregua entre los ejércitos boliviano y paraguayo había sido a criterio de la comisión mixta otro gran obstáculo, puesto que no faltaron reocupaciones de posiciones con la perspectiva de una reiniciación de hostilidades. Las poblaciones bolivianas por donde pasarían los rieles vivían en duras condiciones, profundizadas por la depresión de post-guerra: Yacuiba, era una zona fronteriza de modesto movimiento comercial donde la carencia de instalaciones sanitarias y la escasez de agua potable, habían hecho frecuente el paludismo, enferme-

60 Travassos, Mario: Proyección continental del Brasil, Círculo Militar-Biblioteca del Oficial, Buenos Aires, 1941. La primer edición es de 1930. Quiaca.

61 Fifer: Bolivia..., pág. 353. La red vial caminera argentina llegó en 1939 a Yacuiba y a La 
dad que se hacía aún más violenta conforme se avanzaba hacia el norte; Sanandita - a 27 kilómetros de Pocitos en territorio argentino- constituía el asiento de un importante yacimiento petrolífero de cuya población al menos la mitad eran obreros y que se hallaba rodeado de caseríos cercanos al río Pilcomayo poco menos que despoblados; Villa Montes, que por su situación estratégica era la llave del comercio de la zona de Tarija y Villazón, sufría de la retirada de la mayor parte de las fuerzas militares que se habían concentrado allí procedentes del altiplano. Pero no era mejor la situación del norte de Salta, región chaqueña en donde el comercio era también reducido. ${ }^{62}$ En noviembre de 1943 se había dejado constituida la Comisión Mixta Ferroviaria Argentino-Boliviana, comenzándose en mayo de 1944 los trabajos del ramal en procura de Santa Cruz. En 1946, al comenzar la presidencia de Juan Perón estaban afectados a la obra mil obreros y tres años después la Comisión Mixta tenía a su servicio casi cinco mil trabajadores. A medida que estuvieron concluidos algunos tramos, se fueron habilitando al servicio público con material de tracción y vagones alquilados del Ferrocarril General Belgrano. El ramal completo recién se inauguraría en 1957. Las tensiones originadas por la situación internacional en la región habían conspirado contra la rápida finalización de las obras, como así mismo las periódicas revueltas internas que estallaban en Bolivia, antes y después del asesinato del presidente Gualberto Villarroel en julio de 1946. La dureza del paisaje también hizo lo suyo: el incontrolable desbordamiento de los ríos de las montañas en las planicies del Chaco, la necesidad de construir numerosos puentes, e incluso el asedio de los indígenas. En enero de 1947 los indios protagonizaron un ataque al campamento Petri de la Comisión Mixta, resultaron muertos tres mujeres y dos hombres y numerosos heridos. El ejército boliviano declaró zona militar la región, destacando fuerzas permanentes para la salvaguarda futura de los trabajadores del ferrocarril. ${ }^{63}$

Los gobiernos de la restauración conservadora argentina, más allá de sus desaciertos y de su génesis fraudulenta, habían sido a su vez responsables de iniciativas modernizadoras, que reflejaban una voluntad de hacer

62 National Archives, Maryland, United States (NA), RG 59 - Decimal File 1945-49 - Box 3479, "Proposed Railway between Yacuiba and Santa Cruz - Report of "Comisión Mixta" - BolivianArgentine Comisión, Buenos Aires, marzo de 1940, Memoria correspondiente al tramo Yacuiba-Villa Montes".

63 AMREA, Incidentes fronterizos, Caja 38, 1947, La Paz, 13 de enero de 1947, (fdo.) Buitrago. 
avanzar un proyecto industrialista para el país, ${ }^{64}$ designio en el que la planificación de obras públicas ocupaban un lugar importante. Pero en el caso de la frontera norte argentina, los planes se trazaban y llevaban a cabo sobre un escenario especialmente resistente al cambio. Aún así hubo proyectos destinados a mejorar las comunicaciones, procurándose navegar con regularidad los ríos y mantener eficaces puertos fluviales. En orden a aquellas políticas, se debe señalar que el presidente general ingeniero Agustín Justo creó la Comisión del Canal Lateral del río Bermejo con el objetivo de reforzar la atracción de Bolivia a la influencia rioplatense, dándole una salida fluvial hacia el Atlántico por el Paraná-Río de la Plata y un puerto franco en Rosario, estudios que fueron actualizados en 1935 teniendo en cuenta la promesa del presidente Alvear para dar salida al mar a Bolivia, llegándose a realizar algunos trabajos de campaña por dos comisiones: la del este con asiento en Zapallar (Chaco), y la del oeste, en Embarcación (Salta). Esas acciones, como recuerda Nicolás Boscovich, podían enmarcarse en el desarrollo de una política de penetración hacia el interior, con una serie de recursos que volcados en las fronteras, pretendían también beneficiar a regiones de países vecinos, pero que luego comenzarían a desdibujarse. ${ }^{65}$ Cabe preguntarse si ello llevaba también implícito la voluntad de alcanzar una protointegración regional o era muestra de una pretensión de hegemonía argentina, que buscaba reeditar el espacio del virreinato del Río de la Plata. ${ }^{66}$

En 1941 se firmó en Buenos Aires un acuerdo entre la Argentina, Bolivia y Paraguay para el aprovechamiento de las aguas del río Pilcomayo, y para intentar su navegación, aun cuando sólo fuera en determinadas épocas del año, así como para reglamentar la pesca, el riego o el uso industrial de las aguas. Ya durante el primer mandato de Juan Perón se propició la construcción de diques y canales que llevaran el agua necesaria para el desarrollo económico del norte, pero recién en 1954 el segundo plan quinquenal incluyó un estudio de factibilidad de navegación del Bermejo.

64 Ver Vázquez-Presedo, Vicente: Crisis y retraso. Argentina y la economía internacional entre las dos guerras, Eudeba, Buenos Aires, 1978, pág. 280. The Economist opinaba en un artículo publicado el 8 de febrero de 1936 que pese a su falta de carbón y de hierro, la Argentina se había convertido en el país más industrializado de la América del Sur, con la sola excepción de Brasil.

65 Boscovich, Nicolás: Geoestrategia..., pág. 26-7.

66 Figallo, Beatriz: "La cuestión del Chaco y la integración del Cono Sur", en Unidad y diversidad en América Latina: conflictos y coincidencias, Tomo II, Centro de Graduados-UCA, Buenos Aires, 2000. 
No terminó de llegar la decisión política de hacer viable la navegación y canalización del río Bermejo. ${ }^{67}$

La década del treinta había mostrado también un interés señalado por asegurar la defensa militar de Argentina, vigorizando su industria siderúrgica, cuyos mayores propulsores estaban entre las grandes reparticiones de las Fuerzas Armadas, que aspiraban a beneficiarse de las reservas mineras de Bolivia. Ya en 1936 un decreto creó la Dirección General de Materiales del Ejército, y en 1941, otro la de Fabricaciones Militares, cuyo director general ingeniero Manuel Savio, propuso crear una amplia red de industrias básicas, formadas por sociedades mixtas con el capital privado, destinadas a atender necesidades militares así como demandas civiles. ${ }^{68}$

Fabricaciones Militares logró instalar una planta siderúrgica en Jujuy, donde se habían encontrado yacimientos de hierro, provincia de la que también salieron unas 1.100 toneladas de estaño producidas en 1938, aunque lejos se estaba aún de prescindir del producto importado para la fabricación de pertrechos de guerra. Por todo ello la participación en la explotación minera de la zona de Santa Cruz, especialmente de los importantes yacimientos de hierro en la serranía del Mutún, en el extremo este del Chaco, se constituyó en un objetivo deseable. ${ }^{69}$ A partir de 1944, el gobierno de Villarroel quiso interesar a los de Argentina en la explotación del mineral, pero tal asociación no llegó a concretarse. Los militares bolivianos se plantearon la posibilidad de declarar reserva federal toda la zona, adjudicándola al Ministerio de Defensa, para concertar después con la Dirección General de Fabricaciones Militares una explotación conjunta. Los acontecimientos de julio de 1946 impidieron llegar a la comprobación de la sinceridad de ese propósito. ${ }^{70}$

67 Fenelli, Roberto, "Canalización y aprovechamiento del río Bermejo”, en Congreso Nacional de Historia Argentina, Buenos Aires, 1995. En 1997 Bolivia y la Argentina se plantearon la ejecución de usinas para el aprovechamiento energético y el riego con las aguas del Bermejo. Pero la cuenca del río enfrenta una crítica situación producto de la explotación irracional de recursos naturales, que ha erosionado el otrora rico suelo de áreas de Salta, Jujuy, Formosa y Chaco y la provincia del Gran Chaco de Bolivia.

68 Como señala Schvarzer, Jorge: La industria que supimos conseguir. Una historia políticosocial de la industria argentina, Planeta, Buenos Aires, 1996, pág. 178, las propuestas de Savio se debilitaron luego de su prematura muerte en 1947. Ver también, De Paula, Alberto S.J., Martín, María Haydee, Gutiérrez, Ramón: Los ingenieros militares y sus precursores en el desarrollo argentino. 193080, Tomo II, Fabricaciones Militares, Buenos Aires, 1980; Angueira, María del Carmen-Tirre de Larrañaga, Emilce: Las Fábricas Militares y la industria argentina en el período de entreguerras, C.E.A.L., Buenos Aires, 1995, pág. 65 y ss..

69 AMREA, Bolivia, 1944, Caja 1, Buenos Aires, julio 12 de 1944, del general de brigada Manuel Savio al Cuartel Maestre General del Interior.

70 AMREA, Bolivia, 1946, Expediente 11. Política minera. 


\section{La vigilancia de bienes y personas en la frontera}

Un elemento de gran importancia para el asentamiento de la presencia estatal en las fronteras llegaría con el despliegue de la Gendarmería argentina, que comenzaría por ubicarse en la región del Chaco, considerada como la zona menos segura del país, incluyendo la dotación de modernas armas, de equipos de comunicaciones y de tropas. Sus unidades se establecerían de similar modo que los viejos fortines, cubriendo necesidades de defensa nacional y controlando el tránsito y el tráfico por zonas limítrofes.

Las dificultades productivas de los Territorios de Chaco y de Formosa y la sucesión de asaltos y secuestros ejecutados por bandas organizadas, había acelerado el tratamiento en el Congreso de la ley de creación de la Gendarmería Nacional Militarizada, sancionada en julio de 1938. El objetivo era custodiar los Territorios Nacionales y perseguir el bandolerismo en el norte del país. Constituida como un cuerpo auxiliar de seguridad, integrante de la Fuerza Ejército, pero sometida a leyes y reglamentos propios, su presencia pretendía ser la "reafirmación del ser argentino en regiones donde, por lo alejado del resto del país, los vínculos con lo nacional tienden a debilitarse, cobrando mayor influencia lo extranjero". ${ }^{71}$ En el contexto alarmista de la Segunda Guerra Mundial, el gobierno de Río de Janeiro le asignaría a la creación y luego a la presencia de la Gendarmería en las fronteras con Brasil y Uruguay, la amenazante condición de una segunda línea del Ejército argentino, una reserva dispuesta a ser convocada a la acción, así como expresión de los designios expansionistas platenses. ${ }^{72}$

El accionar de la Gendarmería adquiriría en el norte de la Argentina unas condiciones peculiares, pues sería el elemento militar-policial con que el trasvase de población boliviana y paraguaya pobre y sin trabajo, debió enfrentarse para acceder a la vecina nación, más próspera y crecientemente dispensadora del pleno empleo. Los gendarmes se constituyeron en fuerza restrictiva por excelencia, ejercitando su poder sobre los más débiles, aunque ejerció y ejerce aún funciones más constructivas, como la persecución del narcotráfico, el contrabando y el comercio de la fauna protegida. Quienes detentaban la "nacionalidad de las fronteras" — en un concepto que tiene más la connotación flexible de los espacios regionales que comparten modos de vivir, de producir y de interrelacionarse, que de límite

71 Así es Gendarmería Nacional, Buenos Aires, 1967, pág. 7.

72 Muñoz Svartman, Eduardo: Diplomatas, políticos e militares. As visoes do Brasil sobre a Argentina durante o Estado Novo, EDIUPF, Passo Fundo, 1999, pág. 133. 
político rígido- ${ }^{73}$ comenzaron a coexistir con esta expresión de la autoridad central.

\section{Resistencia y concertación}

Si bien hay una consideración historiográfica que señala que entre 1930 y 1950 el indio chaquense había dejado de ser un amenaza, ${ }^{74}$ al producirse su sedentarización en reservas obligándolo a la práctica de la agricultura e incorporándolo a la mano de obra asalariada de las explotaciones de los blancos, ${ }^{75}$ los supervivientes comenzaron a experimentar una nueva situación, al mermar su requerimiento para la zafra azucarera y otros trabajos temporales a los que por años habían sido conducidos. Si muchos evidenciaron en las décadas del cuarenta y del cincuenta, un proceso lento de incorporación a la vida productiva de la región, otros indígenas mostraron los últimos arrestos de rebeldía.

En 1945 se sucedieron incidentes que mostraban con crudeza los cambios en los modos tradicionales de vida de muchos de los indios chaquenses. Los que vivían dispersos en sus tolderías por la zona sur del Pilcomayo, al asomarse a la zona ribereña en busca de su sustento, se relacionaban habitualmente con pobladores y con efectivos del Ejército paraguayo. Sin embargo el 10 de abril se produjo un choque entre soldados del Fortín Ballivián y unos matacos procedentes de la Argentina, que merodeaban por la zona, resultando muerto uno de los indios y herido un soldado paraguayo. Los indígenas estaban armados con fusiles bolivianos y

73 Gordillo-Leguizamón: El río y la frontera..., pág. 15.

74 Ver Carlos Martínez Sarasola: Nuestros paisanos los indios: vida, historia y destino de las comunidades indígenas en la Argentina, Emecé, Buenos Aires, 1992, págs. 333-355; Mari, Oscar Ernesto: Inseguridad y bandidaje en el Territorio Nacional del Chaco. 1918-1940, Instituto de Investigaciones Geohistóricas, Resistencia, 1994; Giordano, Mariana: Discurso e imagen sobre el indígena en el Chaco Argentino. 1884-1960, Tesis Doctoral, Universidad del Salvador, 2000. Indigentes entre los más pobres de las tres naciones, cabría preguntarse si esa relación conflictiva persiste en términos étnicos, cuando en el siglo XXI las comunidades indígenas chaquenses persiguen su substencia a través del traslado a centros urbanos, propiciando proyectos de turismo intercultural o luchando por sus derechos apelando al método de los piquetes, ver Clarín, Buenos Aires, 12 de noviembre de 2000, "El reclamo de los aborígenes salteños. Cuando los indios se hicieron piqueteros", pág. 24.

75 El Chaco de 1940, Comisión Organizadora de la Primera Gran Exposición del Territorio Nacional del Chaco, Buenos Aires, 1940, pág. 28, señalaba que existía población indígena que mantenía sus hábitos trashumantes, "tan pronto tienen sus tolderías en el Chaco como en Formosa o en Salta", pero "son muchos los indios que se han incorporado a la población general del territorio, confundiéndose con los colonos o trabajadores criollos". 
escopetas recogidas de los abandonados campos de batalla. También ese mes, un contingente de indios, hombres y mujeres, fueron detenidos y pasaron arrestados al Fortín Guachalla, pero al intentar huir había sido muerto un indio, tratándose de un familiar del denominado cacique Julio A. Roca, que se hallaba investido de cierta autoridad por el gobierno argentino en su carácter de jefe de las tribus de matacos, integrados por varios millares de indios sumisos que poblaban una gran extensión de la margen derecha del río Pilcomayo. En su mayoría, trabajaban en los grandes ingenios de azúcar de Salta, pero en los meses que no se cosechaba la caña regresaban a sus aldeas y se dedicaban, según acusaban las autoridades paraguayas, por indicaciones de comerciantes y "hasta de algunas autoridades argentinas poco escrupulosas", a la recuperación, en territorio paraguayo, de materiales abandonados en los bosques y escenarios de la guerra, tales como proyectiles, armas, restos de camiones. Otro incidente se había repetido en julio cuando cuatro indias que estaban recogiendo frutas silvestres fueron sorprendidas por una patrulla del ejército paraguayo, quienes comenzaron a hacerles fuego con sus carabinas. Tres lograron pasar al Chaco argentino, en tanto que la otra jovencita fue tomada prisionera.

Los oficiales de la subcomisaría de Puerto Irigoyen, departamento Bermejo hicieron comparecer al cacique Julio A. Roca, que en su declaración afirmó "ser de nacionalidad argentina, de cuarenta y cinco años de edad, de estado civil casado, de profesión capitán indígena de la "tribu mataco", que no lee ni escribe, firma solamente", asegurando que entre las tolderías existentes en la margen derecha del río Pilcomayo, desde Puerto Irigoyen hasta El Desmonte, "vivían unos quinientos indios, existiendo otros cuatrocientos trabajando en los ingenios de la provincia de Salta, y no habiendo tenido dificultades anteriormente con los paraguayos". Relataba que era costumbre de la indiada pasar a territorio paraguayo, a cazar animales silvestres y recoger frutos de árboles, sin que nunca se les hubiera puesto impedimento para ello, pero que una serie de incidentes habían perturbado aquella convivencia. Finalmente el cacique advertía que ahora "los paraguayos eran malos, porque no los dejaban pescar en el río, ni aún estando en la costa argentina". La política de extrema libertad fronteriza estaba empezando a cambiar, incluso para los indios.

Los fortines fronterizos paraguayos habían recibido órdenes de sus respectivos comandos en el sentido de recorrer las difusas costas del Pilcomayo, prohibiendo la entrada al territorio a los indios que solían tener sus tolderías del lado argentino, pero pasaban a apropiarse de cuanto 
encontraran abandonado en el Chaco, como piezas de automóviles, camiones y vainas servidas, consideradas como patrimonio del estado paraguayo, que se encontraban abandonadas en cantidad, desde que terminó la guerra con Bolivia. Los vecinos blancos de la costa sur informaban que todos los indios de la tribu mataco se hallaban atemorizados por la actitud adoptada por efectivos paraguayos, que patrullaban constantemente su jurisdicción en persecución de aquellos, cuidando que no pasasen al otro lado a recorrer los campos, como siempre lo habían hecho.

No obstante, incidentes graves se sucedían no solo con los aborígenes residentes en territorio argentino, sino también con los asentados en el Paraguay: en los primeros días de agosto los indios de la tribu chunupí, que habitaban en la frontera norte del Pilcomayo, habían atacado el Fortín Oruro de cuya consecuencia resultaron muertos algunos soldados. También ese mes, indígenas de la tribu mataco, con tolderías en la Misión Tucumancito, a veinticinco kilómetros del límite de la provincia de Salta con Formosa, sostuvieron divergencias en la orilla opuesta con los militares del Fortín Ballivián. ${ }^{76}$ Las guarniciones fronterizas paraguayas estaban prevenidas contra malones, que se esperaban cuando terminaran las faenas en los ingenios y los matacos se reintegraran a sus tribus entre los meses de septiembre y octubre. Y aunque eran las mismas autoridades argentinas quienes pasaban aviso a las paraguayas, Asunción se quejaba de la responsabilidad del gobierno en cuyo territorio se originaba el conflicto. ${ }^{77}$

El canciller argentino Cooke le aseguró al embajador paraguayo Francisco Pecci que había instruido al gobernador del Territorio Nacional de Formosa en el sentido de adoptar las medidas necesarias tendientes a mantener el orden en la zona fronteriza, aunque por las informaciones que había recabado, los indios estaban completamente tranquilos, dedicándose al sembradío de sus huertas y la cosecha de sandías y melones. Por de pronto la policía formoseña trataba de controlar a los aborígenes e impedirles el contrabando de cápsulas de proyectil mauser, que se encontraban en la banda paraguaya. Aunque la Argentina también reclamaba ante desplazamientos indios capaces de producir incidentes fronterizos con las tropas de la Gendarmería Nacional. Basándose en información que había proporcionado el jefe del escuadrón Lomitas, en agosto el embajador argentino Victor

76 AMREA, Incidentes fronterizos, 1945, Caja 20, Exp. 7, Puerto Irigoyen, agosto 25 de 1945

77 Archivo del Ministerio de Relaciones Exteriores del Paraguay (en adelante AMREP), Documentación Político-Diplomática (D.P.D.), 430, Asunción, 5 de octubre de 1945, (fdo.) general de brigada Francisco Andino, comandante del Territorio Militar del Chaco. 
Lascano le advertía al canciller paraguayo $\mathrm{H}$. Chiriani sobre la presencia hostil en las cercanías del Fortín Bruguez en Paraguay, de unos mil indios macás, cuyo cacique o jefe era un ciudadano correntino, y entre los que se decía se encontraban algunos de los que participaron en la matanza del personal del argentino Fortín Yunká, un cuarto de siglo atrás. ${ }^{78}$

Desde el oeste al este de la frontera norte de la Argentina, los habitantes de la región, indios o blancos, que la traspasaban tanto para hacer compras en comercios de La Quiaca, Tartagal, Puerto Pilcomayo, Clorinda, Posadas, como para abastecerse de caza y de pesca, comenzaron a vérselas con las trabas que imponían los límites estatales. A pesar de todas las políticas de confraternidad que el régimen peronista propiciaría, especialmente con Bolivia y Paraguay, también se fue requiriendo una mayor legalidad, en vistas a acceder a los derechos del voto popular. Los braceros baratos que se habían hecho cargo de las tareas agrícolas en las provincias limítrofes, sumándose a la fuerza laboral argentina, constituían un caudal político que el peronismo no estaba dispuesto a ignorar. En cuanto los controles se ejercieron, los roces y choques se multiplicaron, gestándose ambientes de sorda hostilidad, que llegaban a expresarse por manifestaciones pueblerinas y en situaciones más graves, por intervención de las fuerzas militares y de las Cancillerías.

El patrullaje para mantener el control aduanero sobre las zonas fronterizas llevado a cabo por el personal de la Dirección General de Gendarmería Nacional, lidiaba de manera permanente con aquellos que pretendían pasar mercaderías al país vecino. Pero el contralor fronterizo no estaba aún organizado según normas estrictas de fiscalización, a pesar que tanto la Dirección de Migraciones, a través de sus destacamentos, como el Tercer Cuerpo de Ejército, intentaban frenar el paso libre por aquellas regiones. ${ }^{79}$ En fechas tan tardías como 1948, la vigilancia en puentes y caminos internacionales eran escasos, ingresando personas de nacionalidad boliviana o paraguaya en su gran mayoría careciendo en absoluto de documentos de identidad o bien con rudimentos de documentación, con excepción de los que no encontrándose comprendidos en la calificación de pasajeros habituales eran obligados a presentarse al destacamento de migraciones por los gendarmes o por la aduana indistintamente. Ese tránsito local o vecinal que

78 AMREP, D.P.D. 430, Asunción, 30 de agosto de 1945, de Victor Lascano a H. Chiriani.

79 AMREA, Incidentes fronterizos, 1948, Caja 43, Informe, (fdo.) Jorge A. Jaunarena, jefe de la zona Noroeste DGM. 
se realizaba en forma completamente liberal siendo tolerado por razones de buena vecindad, era aprovechado para internarse en el país, sin la documentación reglamentaria. A pesar de los certificados que expedía Gendarmería que sólo habilitaban para transitar por las zonas fronterizas el continuo paso de personas desprovistas de documentación, que bajo pretexto de realizar pequeñas compras transitaban por la región sin poseer documentación alguna, era un continuo motivo de fricción. Se reconocía que el contralor de trabajadores contratados por los establecimientos industriales de la zona, con el objeto de dedicarse a tareas rurales, era nulo. Los continuos incidentes fronterizos eran atribuidos a despreocupación de las autoridades nacionales o provinciales en la zona que, absorbidos por el medio hostil en que debían actuar, tendían a relajar los controles. El contrabando había llegado a constituir la principal actividad de aquellos lares, formándose una cierta conciencia de que debía ser tolerada como una fatalidad o una consecuencia lógica de la realidad imperante, pero que en la práctica permitía que comerciantes asentados en las fronteras se constituyeran en abastecedores del sur de Bolivia y del Paraguay, al margen de los convenios en vigencia.

La situación buscó superarse a través de la ley que creó el registro de las personas, ${ }^{80}$ pretendiéndose normalizar la situación de los residentes extranjeros y fiscalizar las entradas y salidas de la Argentina. El objetivo era cimentar en el habitante de las poblaciones fronterizas "la conciencia de sus deberes y obligaciones para con el país que le ha dado asilo". Pero los enfrentamientos siguieron sucediéndose: desde el Escuadrón Clorinda, frente a Asunción, en julio de 1948 se procedió a reprimir el paso de contrabando con mercaderías y artículos de ferretería, concurriendo "agentes de policía del Paraguay que en lugar de reducir civiles que agredían a autoridades argentinas, abrieron fuego contra éstas generalizándose tiroteo siendo necesario emplear armas automáticas pesadas", y pocos meses después en la zona fronteriza de Jujuy debió intervenir el gobierno federal, que decidió la formación de una comisión mixta para investigar choques entre civiles y militares, argentinos y bolivianos. ${ }^{81}$

80 Publicada en el Boletín Oficial del 20 de octubre de 1948, la ley afirmaba que se creaba "el Registro Nacional de las personas, dependiente del Ministerio del Interior, con la misión de registrar y certificar la identidad de todas las personas de existencia visible de nacionalidad argentina o que se hallen en jurisdicción argentina o se domicilien en ella, exceptuándose el personal diplomático extranjero".

81 AMREA, Bolivia, 1948, Caja 43, Informe que presenta la comisión mixta argentino-boliviana a la consideración de ambos gobiernos, La Paz, 30 de noviembre de 1948. 
Si en los cuarenta, el gobierno argentino buscó imponer una creciente legalidad en el tráfico de personas y de bienes desde sus fronteras, también hubo un interés por asegurar un control de tipo político e ideológico en los confines territoriales. En 1947 se creó la Comisión Nacional de Zonas de Seguridad ${ }^{82}$ dentro del Consejo de Defensa Nacional. La misión había sido fijada legalmente en 1946, y señalaba "es indispensable una completa argentinización de las zonas de seguridad de la nación, a fin de que la soberanía en ellas sea también un hecho y no sólo un derecho, además de que los propietarios de los bienes que las comprenden sean argentinos nativos, se requiere que en las dependencias de la nación existentes en ellas el personal directivo, técnico, especializado, administrativo, de maestranza y de servicio sea argentino nativo, lo que deberá conseguirse, progresivamente, antes del 31 de diciembre de 1951. A la vez, igual criterio debe observarse para con el personal de los servicios, compañías, sociedades y establecimientos de toda índole que funcionan en las zonas de seguridad de la nación". Ello se resumía con la conocida denominación de "nacionalización del personal". Para obtenerlo, se procuraba el establecimiento de servicios de registro civil, instrucción pública, religión, policía y juzgado de paz, sanidad, propaganda, correos y telecomunicaciones, servicios de transportes, etc..

\section{Conclusión}

El primer peronismo traería la consolidación de una "nueva frontera", al reforzarse los derechos asociados con la ciudadanía que buscaba definirse en base a la pertenencia a la comunidad organizada de trabajadores, agudizando la necesidad de dar una carácter identitario a la nacionalidad en esos ámbitos marginales del estado. Mientras los habitantes del sur de Bolivia y del Chaco paraguayo, algunos de ellos aborígenes y en su gran mayoría mestizos, no percibían la frontera como un obstáculo a pesar de las medidas de control aduanero y de documentación que se iban imponiendo, y persistían en mantener mutuos vínculos simbólicos y de parentesco con las vecinas regiones de la Argentina ${ }^{83}$ la Gendarmería, ya sin la antigua

82 AMREA, Incidentes fronterizos, 1947, Carpeta de Consulta Permanente, Caja 38, Memorando, Buenos Aires, octubre 24 de 1947, (fdo.) Juan José Tasso, coronel.

83 Hirsch, Silvia M.: "Misión, Región y Nación entre los guaraníes de Argentina. Proceso de integración y de re-etnización en zonas de frontera”, pág. 270-1, en Grimnson: Fronteras... 
pertenencia de sus efectivos a la zona que había caracterizado a las fuerzas militares que la precedieron, vendría a significar la instauración concreta, visible e incluso violenta de que el área fronteriza, y en ese sentido, también el espacio chaquense común, legalmente constituían tres espacios nacionales diferentes. Las gentes de las fronteras continuaron modificando espacios que no habían sido lugares vacíos esperando ser cultivados o zonas de barbarismo aguardando ser civilizados: debieron cohabitar en un escenario ocupado móvil y cambiante, produciendo contactos intensos, donde el poder era enfrentado y contestado ${ }^{84}$ ora con violencia, ora sometiéndose a los controles establecidos, en suma, un área en donde todos los actores negociaban con pasión sus supervivencias.

84 Guy, Donna J. and Sheridan, Thomas E., "On Frontiers", en Guy, Donna J. and Sheridan, Thomas E.: Contested ground: comparative frontiers on the Northern and Southern Edges of the Spanish Empire in the Americas, University of Arizona Press, Tucson, 1998, pág. 11. 